\title{
Properties and Total Initial Activities of Three Oxidative Enzymes Isolated from some Fruits and Vegetables Grown in Egypt
}

\author{
Hafsa N. A. Ebrahem*; Khaled M. Youssef; Zakarya A. S. El-Shamei and Helmy T. Omran \\ Food Technology Dept., Faculty of Agriculture, Suez Canal University, Ismailia, Egypt
}

Received: $5 / 5 / 2016$

\begin{abstract}
The presence of residual endogenous quality-related fruit and vegetable enzymes in either raw or processed fruit or vegetable products may cause loss of quality during processing or storage. The content and properties of such enzymes in these raw sources vary widely with type, species, and variety of the sources and the nature of the environment in which they grew. This study was carried out to determine the optimum conditions ( $\mathrm{pH}$ and temperature) and total initial activities of three quality-related oxidative enzymes [peroxidase (POD), polyphenol oxidase (PPO), and lipoxygenase, (LOX)] in three fruit varieties; mango (Mangifera indica var. Zebda), banana (Musa cavendishii var. Enana), (peel and pulp), olive (Olea europaea var. Picual) and three vegetables; green beans (Phaseolus vulgaris var. Littel Marvel), tomatoes (Lycopersicon esculentum var. Marmand), cucumber (Cucumis sativus var. Ria) grown in Egypt. The POD, PPO and LOX activities were detected in the six examined homogenates. The optimum $\mathrm{pH}$ and temperature values for high enzyme activities were varied according to the type of fruits and vegetables. The highest

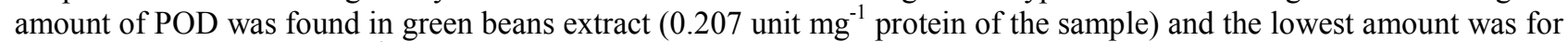

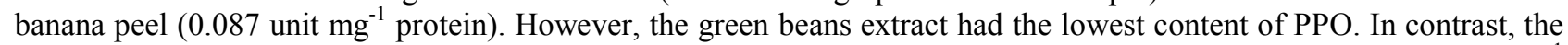
highest content was for banana peel. For LOX activity, the mango extract exhibited the greater extent $\left(0.249 \mathrm{unit}_{\mathrm{mg}}^{-1}\right.$ protein) than cucumber and tomato extracts $\left(0.228\right.$ and 0.211 unit $\mathrm{mg}^{-1}$ protein, respectively). The activity of LOX was very low in the crude banana pulp homogenate $\left(0.068\right.$ unit $\mathrm{mg}^{-1}$ protein).
\end{abstract}

Keywords: Fruits, vegetables, peroxidase, polyphenol oxidase, lipoxigenase

\section{INTRODUCTION}

Enzymes are biocatalysts that are essential in the physiology and metabolism of plants. However, most enzymes remain active postharvest. Although this may be desired in cases where ripening takes place during postharvest storage (Terefe et al., 2014). It is well known that the presence of residual endogenous enzymes in either raw or processed fruit or vegetable products may cause loss of quality during storage (Anthon and Barrett, 2002). It may also lead to detrimental changes in quality attributes such as color, flavor, texture and nutritional value. The activities of endogenous deteriorative enzymes considerably shorten the shelf life of horticultural products. The peroxidase (POD), polyphenoloxidase (PPO) and lipoxygenase (LOX) enzymes may be responsible for other color and flavor changes (Terefe et al., 2014).

With the consumer's increased awareness of health benefits from consuming fresh fruits and vegetables, there is an increasing demand for higher quality of fresh-cut fruits and vegetables in a convenient form. In order to meet these demands, the food industry has focused on the development of new processing techniques for minimally processed fruit and vegetable products. Processing operations, such as peeling, cutting and shredding, induce enzymatic browning and enhance the ethylene synthesis, respiration, softening and microbial contamination, which all correlate with quality deterioration (Son et al., 2001).

On the other hand, contents and properties of enzymes in raw fruit and vegetables vary widely with type, species, and variety of the sources and the nature of the environment in which they grew in.

The changes in ionization of prototropic groups in the active site of an enzyme at lower acid and higher alkali $\mathrm{pH}$ values may prevent proper conformation of the active site, binding of substrates, and/or catalysis of the reaction (Tipton and Dixon, 1983; Whitaker, 1994). In addition, irreversible denaturation of the protein and/or reduction in stability of the substrate as a function of $\mathrm{pH}$ could also influence the catalytic activity of enzymes. Kinetic behavior of some enzymes such as polyphenol oxidase was reported to alter depending on the $\mathrm{pH}$ of the assay which may induce conformational changes in the enzyme (Valero and Garcia-Carmona, 1992; 1998).

Temperature is another important factor that significantly influences the catalytic activity of enzymes. It is well known that a decrease in the kinetic energy of the reactant molecules at low temperatures corresponds to a slower reaction (Nelson and Cox, 2008). In addition, integrity of the delicate threedimensional structure of the enzyme molecule is subjected to disruption and denaturation at high temperatures (Whitaker, 1994).

Valuable information about the initial activities of endogenous enzymes in Egyptian fruits and vegetables is still lacking. So, this study aimed to evaluate the initial activities and the optimum conditions $(\mathrm{pH}$ and temperature) of three oxidative enzymes; POD, PPO, and LOX, the most quality related enzymes in three fruits [banana (B:pe and B:pu), mango (M) and olive $(\mathrm{O})$ ] and three vegetables [green beans $(\mathrm{G})$, tomatoes (T) and cucumber (C)] grown in Egypt.

\section{MATERIALS AND METHODS}

\section{Materials:}

\section{Raw materials}

Mango (Mangifera indica var. Zebda), banana (Musa cavendishii var. Enana), olive (Olea europaea var. Picual), green beans (Phaseolus vulgaris var. Littel Marvel), cucumber (Cucumis sativus var. Ria) and 
tomatoes (Lycopersicon esculentum var. Marmand) were got at ripe stage from Ismailia Governorate local market, Egypt.

\section{Chemicals and reagents}

All fine chemicals used in determination of the enzyme activities were obtained from Sigma-Aldrich chemical company, while the other chemicals (solvents) were of analytical grade.

\section{Methods:}

\section{Preparation of enzyme extracts}

\section{a. Peroxidase (POD) and lipoxygenase (LOX) extracts}

The POD and LOX extracts were prepared according to the method described by Anthon and Barrett (2002) with some modifications. Studied fruits and vegetables raw samples were washed and cut into small pieces. Two hundred grams from each sample was mixed with $200 \mathrm{ml}$ of $0.1 \mathrm{M}$ phosphate buffer ( $\mathrm{pH} \mathrm{6)}$ using a warring blender (Matsushita, ELEC, IND, CO, LTD, Japan). The slurry was homogenized with ultra Turrax homogenizer at $10,000 \mathrm{rpm}$ for $2 \mathrm{~min}$. The resulted homogenate was filtered through cheese cloth and then centrifuged at $3800 \mathrm{xg}$ for $15 \mathrm{~min}$ then the supernatant was filtered (Whatman No 1). This supernatant was used in determination of POD and LOX activities.

\section{b. Polyphenol oxidase (PPO) extracts}

PPO was extracted according to Coseteng and Lee (1987) method, about $200 \mathrm{~g}$ of studied raw materials were homogenized in $400 \mathrm{ml}$ of cold acetone $\left(-25^{\circ} \mathrm{C}\right)$, using a pre-chilled warring blender for $2 \mathrm{~min}$ at maximum speed. The slurry was filtered and the residue was re-extracted with $200 \mathrm{ml}$ of cold acetone. This procedure was repeated until a white powder was obtained. The resultant acetone extract was dried overnight at room temperature and stored at $\left(-25^{\circ} \mathrm{C}\right)$. In order to obtain enzyme extract, a $0.5 \mathrm{~g}$ of acetone powder was suspended in $37.5 \mathrm{ml}$ pre-chilled $0.1 \mathrm{M}$ phosphate buffer ( $\mathrm{pH}$ 6.8), and then stirred for $1 \mathrm{~h}$ at $4^{\circ} \mathrm{C}$. The suspension was centrifuged at $7500 \mathrm{xg}$ for 30 min at $4{ }^{\circ} \mathrm{C}$. The supernatant was used as a crude PPO.

\section{Protein determination}

Protein content of the studied samples was determined spectrophotometerically as described by Janairo et al. (2015) using Biuret reagent test. For the test sample, $1 \mathrm{ml}$ of the sample extract was added to 4.5 $\mathrm{ml}$ of Biuret reagent. The solutions were shaken using a vortex. The color of the solution was observed to be light blue and the absorbance of the protein samples at $545 \mathrm{~nm}$ was determined using the UV-VIS spectrophotometer (6505 UV/ VIS, Jenway LTD, Felsted, Dunmow, UK). A calibration curve $\left(\mathrm{R}^{2}=9998\right)$ of standard protein solution of bovine albumin (0.0 $2.0 \mathrm{mg} / \mathrm{ml}$ ) was prepared and tested under similar conditions.

The $\mathrm{pH}$ and temperature optima of the examined enzymes

The pH optima: The optimum $\mathrm{pH}$ for POD, PPO and LOX activities was determined in the $\mathrm{pH}$ ranged from 4.5- 8.5 using acetate $(4.5$ - 5.5), phosphate $(6.0$ - 8.0) and boric-acid-borax (8.5) buffer adjusted with $0.1 \mathrm{M}$
$\mathrm{NaOH}$ or $0.1 \mathrm{M} \mathrm{HCl}$, using the standard reaction mixture.

The temperature optima: The effect of temperature on the activity of studied enzymes was tested by heating the standard reactions (buffer and substrate) to the appropriate temperatures before addition of the enzyme extract. The activity was assayed at various reaction temperatures controlled by a circulation water bath. The temperature was varied over the range of $10-50{ }^{\circ} \mathrm{C}$. The mixtures of buffer and substrate solution were incubated at the different temperatures. Once temperature equilibrium was reached, the enzyme extract was added to the mixture and the activity was determined spectrophotometrically as rapidly as possible at constant temperature.

\section{Determination of enzyme activities}

Peroxidase activity assay: The POD activity was determined according to the method described by Güneş and Bayindirli (1993). The substrate solution was prepared by mixing $0.5 \mathrm{ml}$ guaiacol (99.5\%), $0.5 \mathrm{ml}$ hydrogen peroxide $(30 \%)$, and $99 \mathrm{ml}$ sodium phosphate buffer ( $\mathrm{pH}$ 6.5). The POD assay was conducted by mixing $0.1 \mathrm{ml}$ enzyme extract with $2.9 \mathrm{ml}$ substrate solution. The increase in absorbance at $470 \mathrm{~nm}$ was measured with $10 \mathrm{~s}$ intervals. One unit of activity was defined as an initial absorbance (OD) change of 0.001/ min under the assay conditions. Standard curve was prepared by plotting the OD values against time. The activity was measured from the linear phase of reaction. One unit of POD activity was defined as the change in OD value per minute per ml of enzyme extract.

Polyphenol oxidase activity assay: The PPO activity was assayed using the procedure of Cano et al. (1997). The enzyme activity was determined by measuring the rate of increase in absorbance at $420 \mathrm{~nm}$ and $25^{\circ} \mathrm{C}$ using spectrophotometer (6505 UV/ VIS, Jenway LTD, Felsted, Dunmow, UK). The reaction mixture contained $2.9 \mathrm{ml}$ of $0.07 \mathrm{M}$ catechol solution in $0.05 \mathrm{M}$ phosphate buffer $(\mathrm{pH} 7.0)$ and $100 \mu \mathrm{l}$ of diluted $(1: 1,0.2 \mathrm{M}$ phosphate buffer $\mathrm{pH} 7$ ) enzyme extract. The activity was calculated on the basis of the slop of the linear portion of the curve of $\Delta A_{420}$ plotted against time (up to $3 \mathrm{~min}$ ). The enzyme activity was expressed as $\Delta A_{420} \mathrm{~min}^{-1} \mathrm{ml}^{-1}$ of enzyme extract.

Lipoxygenase activity assay: The LOX activity was measured by the method described by Bonnet and Croljzet (1977), based on absorption at $234 \mathrm{~nm}$ of the conjugated dines formed when linoliec acid (used as substrate) was oxidized in the presence of LOX. The substrate consisted of $10 \mu \mathrm{l}$ of linoleic acid, $4 \mathrm{ml}$ of $\mathrm{H}_{2} \mathrm{O}, 1 \mathrm{ml}$ of $\mathrm{NaOH}(0.1 \mathrm{~N})$ and $5 \mu \mathrm{l}$ of tween 20 . The mixture was shaken and diluted to $25 \mathrm{ml}$ with distilled water. Each test contained $2.6 \mathrm{ml}$ of phosphate buffer (0.2 M, pH 6.5) was mixed with $0.3 \mathrm{ml}$ of substrate followed by the addition of $100 \mu \mathrm{l}$ crude enzyme extract. The absorbance at $234 \mathrm{~nm}$ was followed over 7 min using spectrophotometer (6505 UV/ VIS, Jenway LTD, Felsted, Dunmow, UK). For blank, $2.6 \mathrm{ml}$ phosphate buffer and $0.3 \mathrm{ml}$ of substrate were used. One unit of LOX activity was defined as 0.1 increases in OD value at $234 \mathrm{~nm} / \mathrm{min}$ under the conditions described above. 


\section{Statistical analysis}

All experiments were done in triplicates. Data were expressed as means \pm standard deviation (SD) by SPSS (version 17.0 SPSS Inc) program.

\section{RESULTS AND DISCUSSION}

\section{The optimum pH and temperature of the POD, PPO} and LOX activities:

Determination of the effects of $\mathrm{pH}$ value and temperature on the POD, PPO and LOX activities was carried out because of their importance in the control of enzymatic reactions in food processing.

\section{Optimum pH}

The effect of $\mathrm{pH}$ on the activity of POD enzymes was determined using buffer solutions at $\mathrm{pH} 4.5-8.5$ (Figure, $1 \mathrm{~A}$ and B). As seen in Figure (1-A), M-POD extract showed maximum activity at $\mathrm{pH} 5.5$ followed by a sharp decrease with increasing the $\mathrm{pH}$ value. Khan and Robinson (1994) reported that the optimum $\mathrm{pH}$ of purified mango isoperoxidase varied from $\mathrm{pH} 5.0$ - 6.25. On the other hand, the optimum $\mathrm{pH}$ for mango soluble POD was 5.0, while ionically bound POD was 4.5 -5.0. For B:pe-POD and B:pu-POD the optimum activities were observed at $\mathrm{pH} 6.5$ and $\mathrm{pH}$ 6, respectively (Figure, 1-A). Similar results were obtained by Nagle and Haard (1975). They found that the maximum activity for ripe banana POD was between $\mathrm{pH} 5.0$ - 6.0. While, MacDonald and Schaschke (2000) studied the POD activity in banana at $\mathrm{pH}$ value of 7.0. T-POD exhibited optimum activity at $\mathrm{pH} 7.5$ (Figure, 1-B). Suha et al. (2013) found that, T-POD revealed optimum activity at pH 7.0 - 8.0. From the same figure it was observed that the maximum activity of C-POD was at $\mathrm{pH}$ 7.0. Similar results were reported by $\mathrm{Zhu}$ et al. (2004) who mentioned that, the optimum activity for C-POD enzyme was at $\mathrm{pH}$ 7.0. Furthermore, Figure (1-B) demonstrated that, the optimum $\mathrm{pH}$ for G-POD activity was at $\mathrm{pH}$ 6.5. This behavior was similar to that used by Akyol (2004). Who measured the G-POD activity at optimum $\mathrm{pH}$ value of 6.5 during inactivation the enzyme by some methods such as high hydrostatic pressure and blanching at moderate temperatures (20$70{ }^{\circ} \mathrm{C}$ ). Finally it can be seen that, the maximum activity for O-POD was detected at $\mathrm{pH} 7.0$ (Figure, 1-B). The maximum activity of O-POD was found at $\mathrm{pH} 7.0$ and decreased steeply for higher and lower values of $\mathrm{pH}$ (Saraiva et al., 2007). In general, POD activity in plants shows variation in $\mathrm{pH}$ optima and this is depending on plant variety and substrate. The literature has been reported that, the optimum $\mathrm{pH}$ for maximum activity of POD were 5.4 in grape, $4.5-5.0$ in banana, 4.2 in pineapple, 5.0 - 5.4 in potato, 5.5 in cabbage leaves, 5.2 in strawberries and 4.0 in marula fruit (Billaud et al., 1999; Martínez et al., 2001; Mdluli, 2005; Kharatmol and Pandit, 2012).
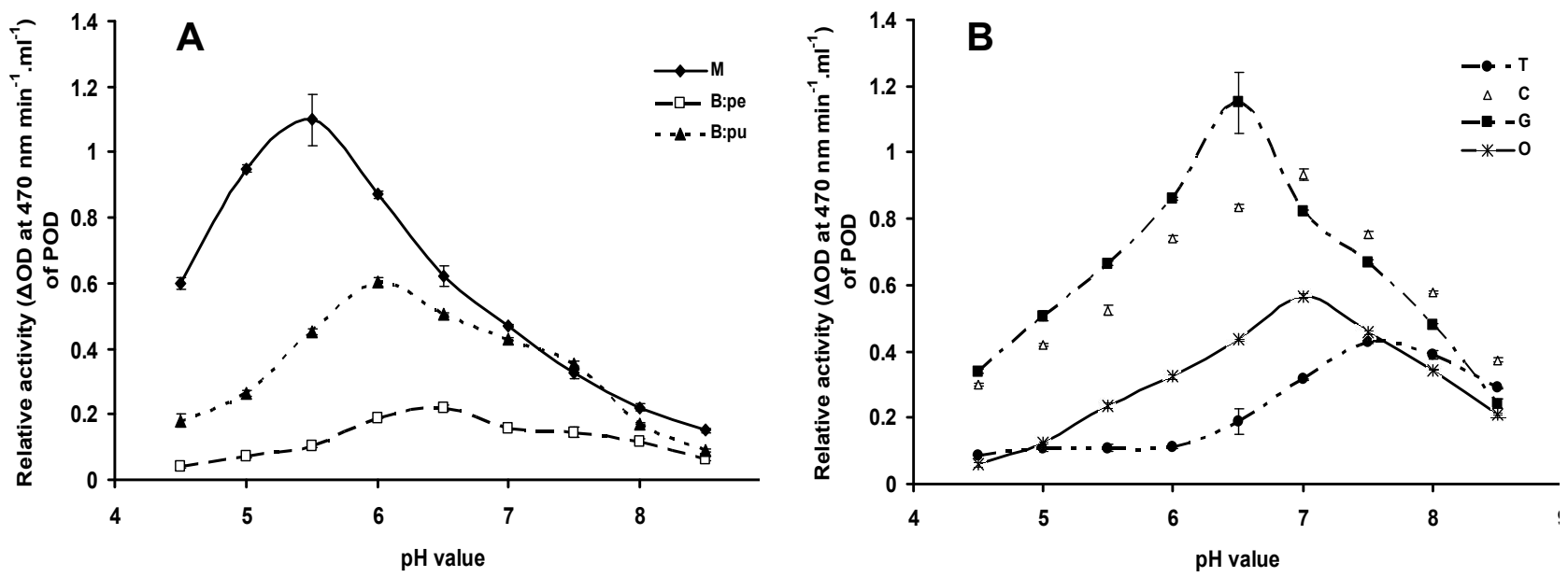

Figure (1): $\mathrm{pH}$ profiles of POD activity for investigated samples in $0.1 \mathrm{M}$ acetate buffer (4.5 - 5.5), $0.1 \mathrm{M}$ phosphate buffer $(6-8)$ and $0.1 \mathrm{M}$ boric acid-borax buffer (8.5). The reaction medium containing $2.9 \mathrm{ml} 129.63 \mathrm{mM}$ guaiacol, 2.9 $\mathrm{ml} 129.63 \mathrm{mM} \mathrm{H}_{2} \mathrm{O}_{2}$ and $0.1 \mathrm{ml}$ of enzyme extract.

The optimum pHs for PPO of M, B:pe and B:pu were performed (Figure, 2-A). PPO showed $\mathrm{pH}$ optima at 7.0 in both B:pe and B:pu. The optimum $\mathrm{pH}$ of PPO activity varies widely with plant source but it is generally in the range of $4.0-8.0$ (Yoruk and Marshall, 2003). Optimal value of $\mathrm{pH} 60$ for M-PPO with catechol as a substrate have also been reported by Labib (1992). However, Yang et al. (2000) remarked an optimum $\mathrm{pH}$ for PPO banana pulp at $\mathrm{pH} 6.5$ and the enzyme activity was stable in the range of $\mathrm{pH} 5-11$ at 5 ${ }^{\circ} \mathrm{C}$ for $48 \mathrm{~h}$. Also, from Figure (2-B) it can be noticed that the T-PPO, C-PPO and, G-PPO had their maximal activities at $\mathrm{pH}$ 7.0. Identical results have been obtained by Lokhandwala and Bora (2014). They declared that, the optimum $\mathrm{pH}$ for tomato PPO activity was 7.0 in 0.1 $\mathrm{M}$ sodium phosphate buffer. Likewise, they reported that the enzyme activity measured at this $\mathrm{pH}$ was 53.54 $\mu$ moles $/ \mathrm{ml} / \mathrm{min}$. However, PPO was found more stable between the ranges of $\mathrm{pH} 8$ to $\mathrm{pH} 10$ in $0.1 \mathrm{M}$ sodium phosphate buffer after incubation of 8 days. The PPO activity reduced to zero at $\mathrm{pH} 1,2$ and 3 after incubation for 6,7 and 8 days, respectively; which indicated that 
PPO was more stable at alkaline pH. Guo et al. (2009) claimed that the all isoforms of G-PPO activities were stable between $\mathrm{pH} 6.8$ and $\mathrm{pH} 7.2$, but they lost $90 \%$ of their original activities when adjusted to a $\mathrm{pH}$ below 6.2 or above 8.0. So the change of $\mathrm{pH}$ would greatly influence the stability of PPO in green beans. As well as the O-PPO had maximum activity at $\mathrm{pH} 6.0$ (Figure, 2B). Similar results were obtained by Ortega-Garcia et al.
(2008) who reported that the optimum $\mathrm{pH}$ of Olea europaea was 6.2. Generally, several researchers found that PPOs were stable near neutral $\mathrm{pH}$ and were unstable in acidic media, such as for longan fruit and yali pear (pH 7.0) (Zhow and Feng, 1991; Jiang, 1999), artichoke ( $\mathrm{pH} \mathrm{6.0-} \mathrm{7.0)} \mathrm{(Aydemir,} \mathrm{2004),} \mathrm{and} \mathrm{marula}$ fruit (pH 6.0) (Mdluli, 2005).
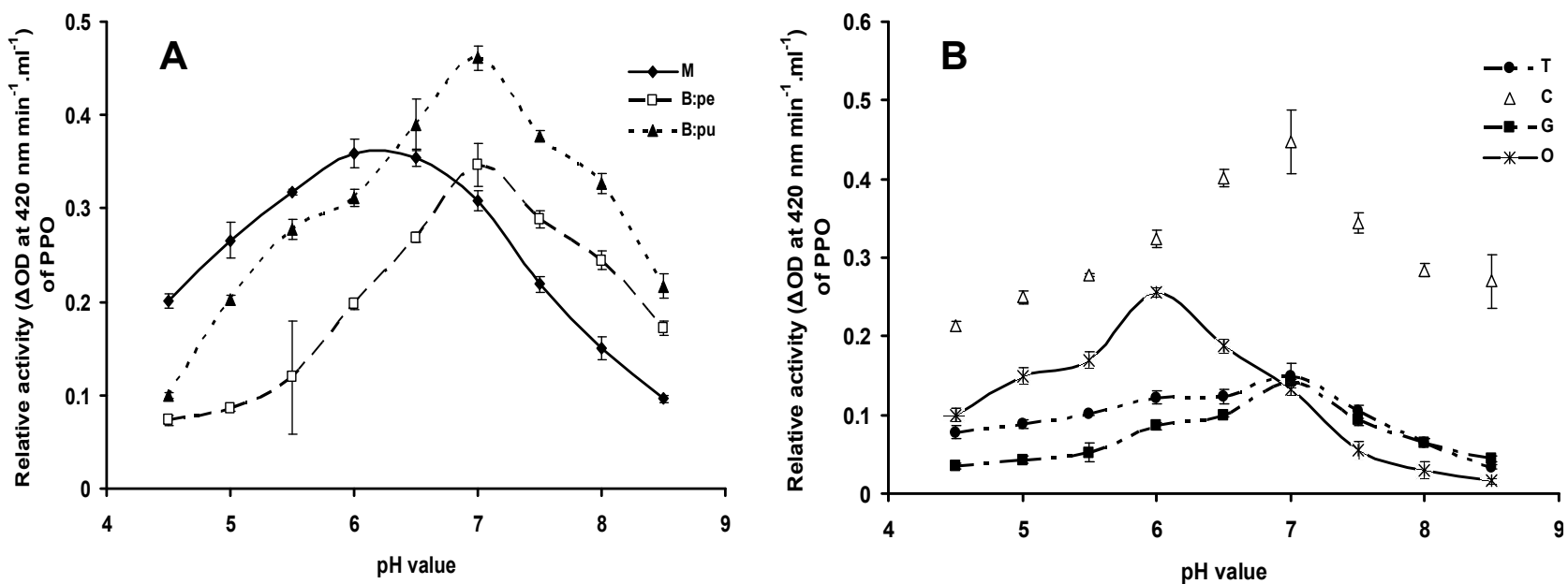

Figure (2): $\mathrm{pH}$ profiles of PPO activity for investigated samples in $0.1 \mathrm{M}$ acetate buffer (4.5 - 5.5), 0.1 M phosphate buffer $(6-8)$ and $0.1 \mathrm{M}$ boric acid-borax buffer $(8.5)$. The reaction medium containing $2.5 \mathrm{ml} 1.25 \mathrm{mM}$ catechol and 0.5 $\mathrm{ml}$ of enzyme extract

The effect of $\mathrm{pH}$ on LOX activities of the seven plant materials was carried out (Figure, 3 A and B). For $\mathrm{M}$ extract, LOX showed maximum activity at $\mathrm{pH}$ 6.5. Rayan (2009) found the same result. While, Ding et al. (2007) studied the M-Lox activity during storage period at $\mathrm{pH}$ value of 7.0. In both B:pe and B:pu, the optimum $\mathrm{pH}$ for LOX activity was at 7.0 (Figure, 3-A). Kuo et al. (2006) found that the optimal $\mathrm{pH}$ of the purified LOX from banana leaf was 6.2 and at $\mathrm{pH} 5.5,84 \%$ activity was observed, while only $11 \%$ activity at $\mathrm{pH} 8.0$. The T-LOX enzyme demonstrated maximum activity at $\mathrm{pH}$ 6.0 (Figure, 3-B). A similar optimum $\mathrm{pH}$ was found at pH 6.0 by Bowsher et al. (1992). The C-LOX showed height activity at pH 5.5 (Figure, 3-B). For G-LOX and O-LOX (Figure, 3-B) optimum activities were at $\mathrm{pH}$ 6.0. Indrawati et al. (2000) and Lorenzi et al. (2006) found equal figure. They reported that olive LOX activity showed its maximum at $\mathrm{pH} 6.0$.
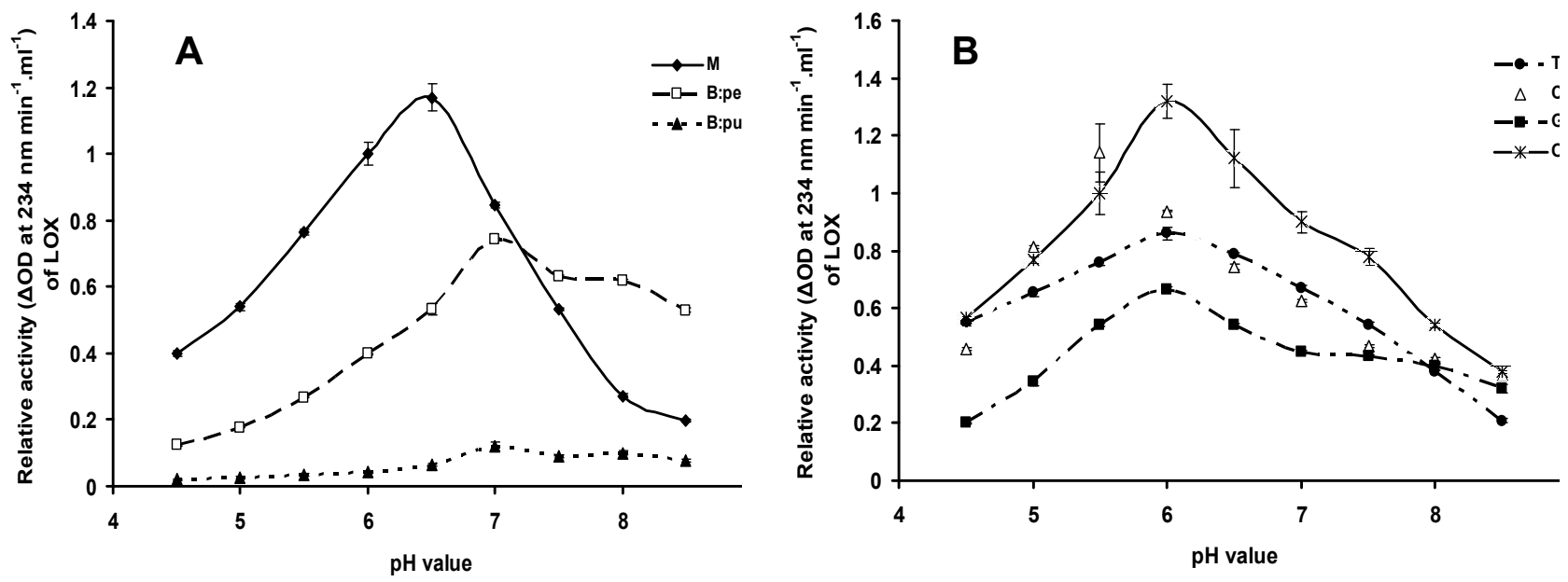

Figure (3): $\mathrm{pH}$ profiles of LOX activity for investigated samples in $0.1 \mathrm{M}$ acetate buffer (4.5 - 5.5), 0.1 M phosphate buffer $(6-8)$ and $0.1 \mathrm{M}$ boric acid-borax buffer (8.5). The reaction medium containing $2.9 \mathrm{ml} 1.2 \mathrm{mM}$ linoleic acid and $0.1 \mathrm{ml}$ of enzyme extract 


\section{Optimum temperature}

Reaction mixtures were prepared as described in materials and methods and then incubated at different temperatures $\left(10-50{ }^{\circ} \mathrm{C}\right)$. Relative POD activities obtained from these tests are shown in (Figure, $4 \mathrm{~A}$ and B). Under the used working conditions, the M-POD had optimum temperature at $20{ }^{\circ} \mathrm{C}$ and stayed active at temperatures $25-30{ }^{\circ} \mathrm{C}$ (Figure, 4-A). Sugai and Tadini (2006) found similar results, where they reported that the suitable temperature for determination the POD activity of mango puree was at $25^{\circ} \mathrm{C}$. Rayan (2009) found that, the optimum temperature for M-POD activity was at $40{ }^{\circ} \mathrm{C}$, and high activities at temperature ranged between $20-50{ }^{\circ} \mathrm{C}$, were occurred. The B:pePOD and B:pu-POD displayed a maximum activity at
$30{ }^{\circ} \mathrm{C}$ (Figure, 4-A). Yadav et al. (2012) mentioned that purified POD from banana stem had optimum temperature at $25{ }^{\circ} \mathrm{C}$. Additionally, Figure (4-B) demonstrates that the optimum temperatures for $\mathrm{T}, \mathrm{C}$ and G-POD activities were at $25{ }^{\circ} \mathrm{C}$. Similar results were announced by Quiroga et al. (2000), Akyol (2004) and Battistuzzi et al. (2004). They found that the activities of POD extracted from tomato, green beans and cucumber were optimum between $25-30{ }^{\circ} \mathrm{C}$. With regard to O-POD its optimum temperature was at $35^{\circ} \mathrm{C}$. Tzika et al. (2009) studied the effect of the reaction temperature on the initial rate of olive POD catalyzed ABTS oxidation from 10 to $50^{\circ} \mathrm{C}$ and observed that the optimal temperature for O-POD was between 25 and 30 ${ }^{\circ} \mathrm{C}$.
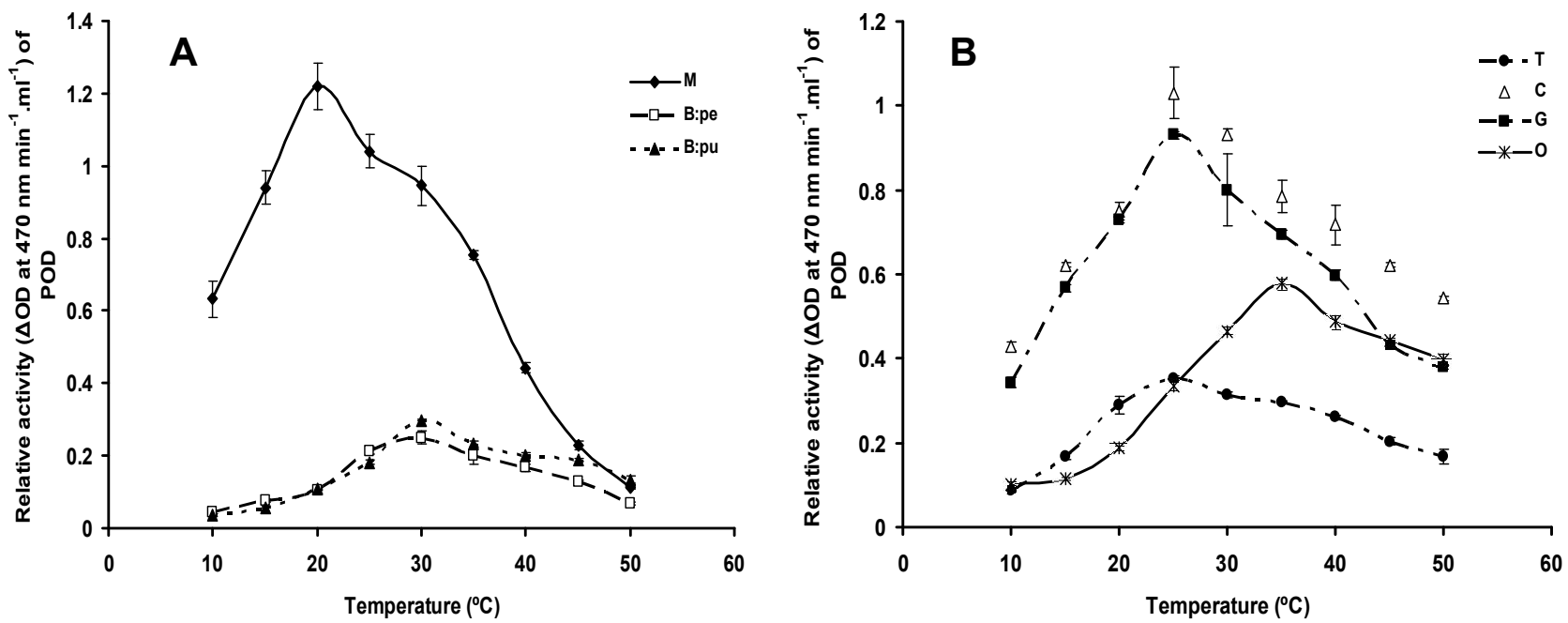

Figure (4): Effect of temperature on POD activity of investigated samples at optimum $\mathrm{pH}$ value for each. The reaction medium containing $2.9 \mathrm{ml} 129.63 \mathrm{mM}$ guaiacol, $2.9 \mathrm{ml} 129.63 \mathrm{mM} \mathrm{H}_{2} \mathrm{O}_{2}$ and $0.1 \mathrm{ml}$ of enzyme extract

Effect of temperature on PPO activity is shown in Figure (5 A and B). M-PPO displayed a maximum activity at $30{ }^{\circ} \mathrm{C}$ (Figure, 5-A). This result is in agreement with those obtained by Robison et al. (1993) and Rayan (2009). They noted that the optimum temperature of M-PPO was $30{ }^{\circ} \mathrm{C}$ using 4methylcatechol as a substrate. The data also expedited that, the B:pe-PPO and B:pu-PPO had the same optimum temperature $\left(30^{\circ} \mathrm{C}\right)$. Yang et al. (2000) found that the optimum temperature of banana pulp PPO was at $30^{\circ} \mathrm{C}$. On the other hand, it can be seen that the maximum activity for T-PPO was achieved at $35^{\circ} \mathrm{C}$ Figure (5-B). Lokhandwala and Bora (2014) mentioned that the optimum temperature for T-PPO activity was at $40{ }^{\circ} \mathrm{C}$ and the activity obtained was $43.32 \mu$ moles/ min/ $\mathrm{ml}$. For C-PPO, the optimum temperature was $40{ }^{\circ} \mathrm{C}$. Millar et al. (1990) revealed that C-PPO had optimum temperature at $50{ }^{\circ} \mathrm{C}$. Further, Figure (5-B) illustrates that G-PPO had maximum activity at $35^{\circ} \mathrm{C}$. Guo et al. (2009) reported that there are four isoforms of (PPOs) were characterized in purified extracts of coats (PPOIa and PPOIb) and pods (PPOIIa and PPOIIb) of green beans. The effects of temperatures between 0 and $80{ }^{\circ} \mathrm{C}$ on the PPOs activities showed that optima temperatures for PPOIa, PPOIb and PPOII were 20,30 and $50{ }^{\circ} \mathrm{C}$, respectively. The O-PPO extract showed maximum activity at $35^{\circ} \mathrm{C}$ (Figure 5-B). In a study carried out by Ortega-Garcia et al. (2008) olive fruits PPO showed optimum activity at $30^{\circ} \mathrm{C}$.

Figure (6, A and B) is showing the effect of temperature on LOX activity. As seen in Figure (6-A) M-LOX had an optimum temperature at $35{ }^{\circ} \mathrm{C}$. Additionally, at the same Figure verify that LOX of B:pe and B:pu, exhibited their highest activities at 35 and $30^{\circ} \mathrm{C}$, respectively. However, from Figure (6-B) it can be detected that T-LOX, G-LOX and O-LOX possessed optimum temperature at $30^{\circ} \mathrm{C}$. But C-LOX the maximum activity was found at $15{ }^{\circ} \mathrm{C}$. Matsui et al. (1999) observed that the optimum temperature for CLOX was at $25{ }^{\circ} \mathrm{C}$ with free fatty acid (linoleic acid) as a substrate. Lorenzi et al. (2006) confirmed that the OLOX was stable up to $60{ }^{\circ} \mathrm{C}$ and remained stable at -20 ${ }^{\circ} \mathrm{C}$ for more than 1 year It was particularly thermostable in comparison to 13-LOX tomato isoforms (Anthon and Barrett, 2003). 

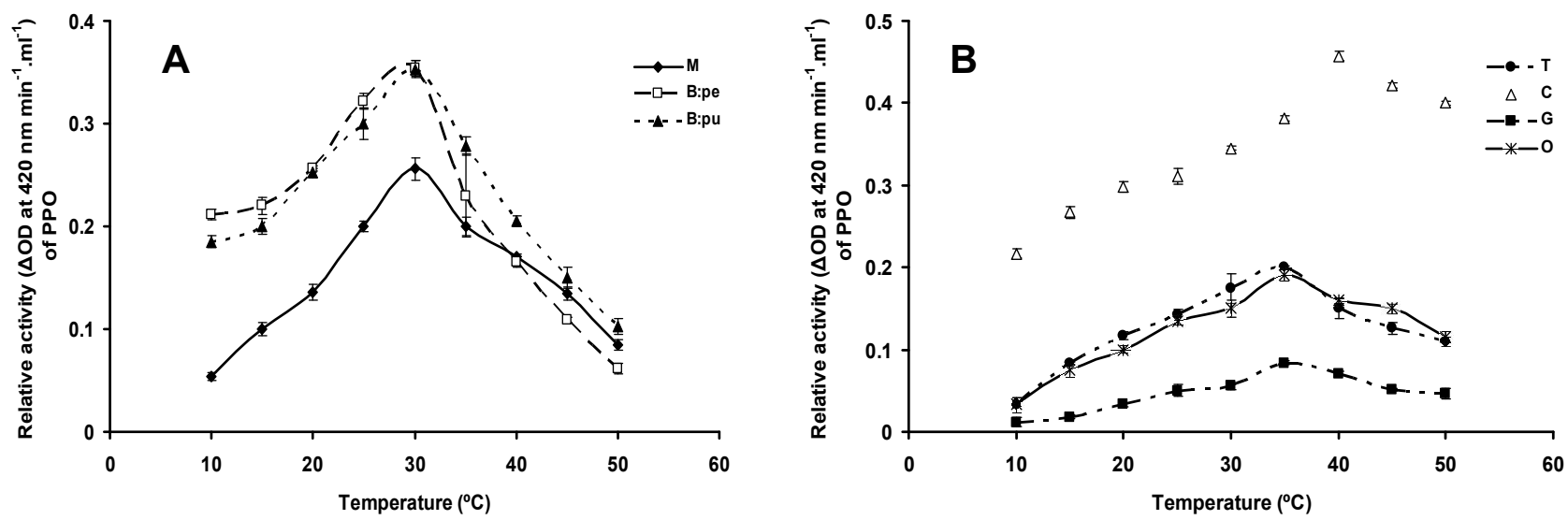

Figure (5): Effect of temperature on PPO activity of investigated samples at optimum $\mathrm{pH}$ value for each. The reaction medium containing $2.5 \mathrm{ml} 1.25 \mathrm{mM}$ catechol and $0.5 \mathrm{ml}$ of enzyme extract
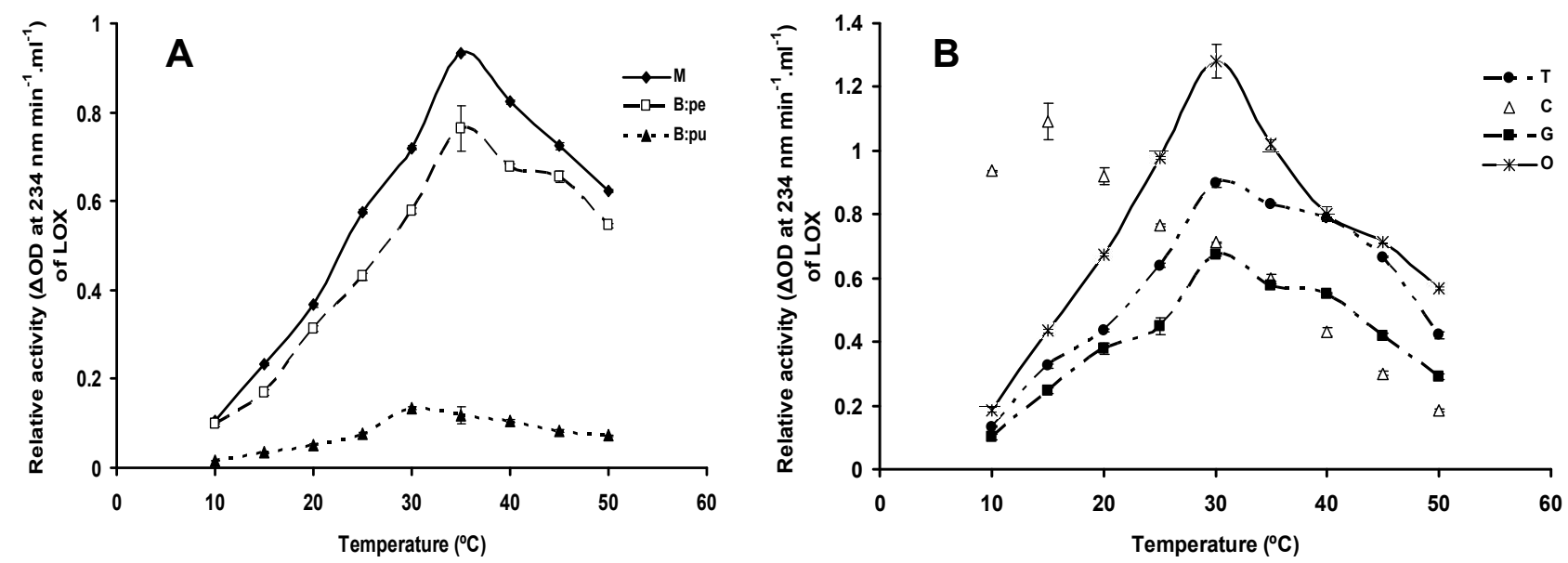

Figure (6): Effect of temperature on LOX activity of investigated samples at optimum $\mathrm{pH}$ value for each. The reaction medium containing $2.9 \mathrm{ml} 1.2 \mathrm{mM}$ linoleic acid and $0.1 \mathrm{ml}$ of enzyme extract

Total initial activities of the POD, PPO and LOX enzymes

As seen in Table (1) the highest amount of POD was found in $\mathrm{G}$ extract $\left(0.207\right.$ unit $\mathrm{mg}^{-1}$ protein of the sample). Similar result was found by Fernandes et al. (2007). Also, Regalado et al. (2004) reported that GPOD is considered to have an empirical relationship with deterioration in flavor, color, texture and nutritional qualities of raw and processed G. However, the other fruit and vegetable extracts were differed in POD activity (Table 1). The POD activity in $\mathrm{M}$ extract was greater than that for $\mathrm{T}$ or $\mathrm{C}$ and the lowest activity was for B:pe (0.087 unit $\mathrm{mg}^{-1}$ protein). Sathya (2014) found low amount of Bpe-POD due to that B:pe contains various antioxidant compounds which in turn reflects on the activity of POD.

The B:pu extract (Table 2) contained the greatest content of PPO (0.365 unit $\mathrm{mg}^{-1}$ protein) which causes undesirable browning in tissue as reported by Sojo et al. (1998). According to Yang et al. (2000), in the peel and pulp of B, dopamine was detected in large quantity, and it was strongly oxidized by the crude and/ or partially purified PPO. These results indicated that the enzymatic browning in B:pe or pu appears to be due to the oxidation of dopamine by the endogenous PPO. While, G-PPO gave the lowest content $\left(0.083\right.$ unit $\mathrm{mg}^{-1}$ of protein), it was contrast with Guo et al. (2009) who found that green beans pods had a high PPO content (4.5 unit $\mathrm{mg}^{-1}$ of protein).

With regard to LOX activity (Table 3), the mentioned extracts displayed reasonable activities fall between $0.068-0.249$ unit $\mathrm{mg}^{-1}$ protein. Mango pulp had the highest amount of LOX (0.249 unit $\mathrm{mg}^{-1}$ protein) compared with the other fruits and vegetables extracts. Similar results were found by Rayan (2009) who found that the mango pulp had higher LOX activity than that for cauliflower heads. The high content of MLOX is responsible for loss of yellow color in the M slices which undergo co-oxidation of carotenoid by reacting with hydroperoxides formed by lipoxygenasemediated oxidation of polyunsaturated fatty acids. Chedea and Jisaka (2013) reported that LOX catalyzes the oxidation of polyunsaturated fatty acids. When LOX oxidizing unsaturated fatty acids co-oxidizes carotenoids many or all of their biological functions will be lose. The B:pu had the lowest activity (0.068 unit $\mathrm{mg}^{-1}$ protein) and this may be due to its high content from antioxidants as already mentioned. 
Table (1): Summary of POD activities ${ }^{*}$ in the investigated fruits and vegetables

\begin{tabular}{|c|c|c|c|}
\hline \multirow[b]{2}{*}{ Fruits and vegetables } & \multicolumn{3}{|c|}{ POD activity ${ }^{* * *}$} \\
\hline & $\begin{array}{l}\text { Relative activity } \\
\left(\Delta \text { OD } \text { min }^{-1} \cdot \mathrm{ml}^{-1}\right)\end{array}$ & $\begin{array}{l}\text { Total activity } \\
\left(\text { Unit } 100 \mathrm{~g}^{-1}\right)\end{array}$ & $\begin{array}{c}\text { Specific activity } \\
\text { (unit } \mathrm{mg}^{-1} \text { of protein) }\end{array}$ \\
\hline Mango (M) & 0.900 & 504.00 & 0.206 \\
\hline $\begin{array}{r}\text { Banana (B): } \\
\text { Peel (pe) } \\
\text { Pulp(pu) }\end{array}$ & $\begin{array}{l}0.230 \\
0.300\end{array}$ & $\begin{array}{c}96.60 \\
137.00\end{array}$ & $\begin{array}{l}0.087 \\
0.126\end{array}$ \\
\hline Tomato (T) & 0.854 & 515.50 & 0.176 \\
\hline Cucumber (C) & 0.860 & 526.50 & 0.193 \\
\hline Green beans (G) & 1.480 & 777.00 & 0.207 \\
\hline Olive (O) & 0.250 & 126.85 & 0.089 \\
\hline
\end{tabular}

"Means of three replicates

${ }^{* *}$ All reactions have been carried out under the optimum conditions for the enzyme

- One unit of POD activity was defined as the change in OD value at $470 \mathrm{~nm}$ per minute per $\mathrm{ml}$ of enzyme

Table (2): Summary of PPO activities ${ }^{*}$ in the investigated fruits and vegetables

\begin{tabular}{|c|c|c|c|}
\hline \multirow[b]{2}{*}{ Fruits and vegetables } & \multicolumn{3}{|c|}{ PPO activity ${ }^{* *}$} \\
\hline & $\begin{array}{l}\text { Relative activity } \\
\left(\Delta O D \text { min }^{-1} \cdot \mathrm{ml}^{-1}\right)\end{array}$ & $\begin{array}{l}\text { Total activity } \\
\left(\text { Unit } 100 \mathrm{~g}^{-1}\right)\end{array}$ & $\begin{array}{c}\text { Specific activity } \\
\text { (unit } \mathrm{mg}^{-1} \text { of protein) }\end{array}$ \\
\hline Mango (M) & 0.300 & 47.25 & 0.210 \\
\hline $\begin{array}{r}\text { Banana (B): } \\
\text { Peel (pe) } \\
\text { Pulp(pu) }\end{array}$ & $\begin{array}{l}0.345 \\
0.460\end{array}$ & $\begin{array}{l}39.35 \\
38.60\end{array}$ & $\begin{array}{l}0.138 \\
0.365\end{array}$ \\
\hline Tomato (T) & 0.140 & 14.40 & 0.089 \\
\hline Cucumber (C) & 0.420 & 57.37 & 0.317 \\
\hline Green beans (G) & 0.100 & 13.80 & 0.083 \\
\hline Olive (O) & 0.206 & 22.95 & 0.112 \\
\hline
\end{tabular}

Means of three replicates

** All reactions have been carried out under the optimum conditions for the enzyme

- One unit of PPO activity was defined as the change in OD value at $420 \mathrm{~nm}$ per minute per $\mathrm{ml}$ of enzyme

Table (3): Summary of LOX activities ${ }^{*}$ in the investigated fruits and vegetables

\begin{tabular}{|c|c|c|c|}
\hline \multirow[b]{2}{*}{ Fruits and vegetables } & \multicolumn{3}{|c|}{ LOX activity $^{* *}$} \\
\hline & $\begin{array}{l}\text { Relative activity } \\
\left(\Delta \mathrm{OD} \mathrm{min}^{-1} \cdot \mathrm{ml}^{-1}\right)\end{array}$ & $\begin{array}{l}\text { Total activity } \\
\text { (Unit } 100 \mathrm{~g}^{-1} \text { ) }\end{array}$ & $\begin{array}{c}\text { Specific activity } \\
\text { (unit } \mathrm{mg}^{-1} \text { of protein) }\end{array}$ \\
\hline Mango (M) & 1.146 & 7.161 & 0.249 \\
\hline $\begin{array}{r}\text { Banana (B): } \\
\text { Peel (pe) } \\
\text { Pulp(pu) }\end{array}$ & $\begin{array}{l}0.744 \\
0.120\end{array}$ & $\begin{array}{l}3.013 \\
0.387\end{array}$ & $\begin{array}{l}0.177 \\
0.068\end{array}$ \\
\hline Tomato (T) & 0.926 & 5.000 & 0.211 \\
\hline Cucumber (C) & 1.140 & 6.327 & 0.228 \\
\hline Green beans (G) & 0.664 & 3.237 & 0.132 \\
\hline Olive (O) & 1.060 & 5.155 & 0.231 \\
\hline
\end{tabular}

Means of three replicates

${ }^{* *}$ All reactions have been carried out under the optimum conditions for the enzyme

- One unit of LOX activity was defined as 0.1 increase of OD at $234 \mathrm{~nm}$ per ml of enzyme 


\section{REFERENCES}

Akyol, Ç. (2004). Inactivation of peroxidase and lipoxygenase in green beans, peas and carrots by a combination of high hydrostatic pressure and mild heat treatment. M.Sc. Thesis, Middle East Technical University, Turkey.

Anthon, G. E. and D. M. Barrett (2002). Kinetic parameters for the thermal inactivation of quality-related enzymes in carrots and potatoes. J. Agric. Food Chem., 50: 4119-4125.

Anthon, G. E. and D. M. Barrett (2003). Thermal inactivation of lipoxygenase and hydroperoxytrienoic acid lyase in tomatoes. Food Chem., 81: 275-279.

Aydemir, T. (2004). Partial purification and characterization of polyphenol oxidase from artichoke (Cynara scolymus L.) heads. Food Chem., 87: 59-67.

Battistuzzi, G., M. Bellei, C. A. Bortolotti, G. Di Rocco, A. Leonardi and M. Sola (2004). Characterization of the solution reactivity of a basic heme peroxidase from Cucumis sativus. Archives Biochem. Biophysic., 423: 317-331.

Billaud, C., L. Louarime and J. Nicolas (1999). Ficus sycomorus latex: A thermostable peroxidase. J. Food Biochem., 23: 145-172.

Bonnet, J. L. and J. Croljzet (1977). Lipoxygenase from tomato fruit: Partial purification and study of some properties. J. Food Sci., 42: 625-628.

Bowsher, C. G., B. J. M. Ferrie, S. Ghosh, J. Todd, J. E. Thompson and S. J. Rothstein (1992). Purification and partial characterization of a membrane-associated lipoxygenase in tomato fruit. Plant Physiol., 100: 1802-1807.

Cano, M. P., B. De Ancos, M. G. Lobo and M. Santos (1997). Improvement of frozen banana (Musa cavendishii, cv. Enana) colour by blanching: relationship between browning, phenols and polyphenol oxidase and peroxidase activities. Zeitschrift für Lebensmittel untersuchung undForschung A, 204: 60-65.

Chedea, V. S. and M. Jisaka (2013). Lipoxygenase and carotenoids: A co-oxidation story. African J. Biotechnol., 12: 2786-2791.

Coseteng, M. Y. and C. Y. Lee (1987). Changes in apple polyphenol oxidase and polyphenol concentrations in relation to degree of browning. J. Food Sci., 52: 985-989.

Ding, Z., S. Tian, X. Zheng, Z. Zhou and Y. Xu (2007). Responses of reactive oxygen metabolism and quality in mango fruit to exogenous oxalic acid or salicylic acid under chilling temperature stress. Physiol. Plant., 130: 112-121.

Fernandes, S. C., I. R. W. Z. de Oliveira and I. C. Vieira (2007). A green bean homogenate immobilized on chemically cross linked chitin for determination of caffeic acid in white wine. Enzyme and Microbial Technol., 40: 661-668.

Güneş, B. and A. Bayindirli (1993). Peroxidase and lipoxygenase inactivation during blanching of green beans, green peas and carrots. LWT, 26: 406-410.
Guo, L., Y. Ma, J. Shi and S. Xue (2009). The purification and characterisation of polyphenol oxidase from green bean (Phaseolus vulgaris L.). Food Chem., 117: 143-151.

Indrawati, Van, A. M. Loey, L. R. Ludikhuyze and M. E. Hendrickx (2000). Kinetics of pressure inactivation at subzero and elevated temperature of lipoxygenase in crude green bean (Phaseolus vulgaris L.) extract. Biotechnol. Progress, 16: 109-115.

Janairo, G., M. S. Linley, L. Yap, N. Llanos-Lazaro and J. Robles (2015). Determination of the sensitivity range of biuret test for undergraduate biochemistry experiments. e-J. Sci. Technol., 6: 81-87.

Jiang, Y. (1999). Purification and some properties of polyphenol oxidase of longan fruit. Food Chem., 66: 75-79.

Khan, A. A. and D. S. Robinson (1994). Hydrogen donor specificity of mango isoperoxidase. Food Chem., 49: 407-410.

Kharatmol, P. P. and A. B. Pandit (2012). Extraction, partial purification and characterization of acidic peroxidase from cabbage leaves (Bresicca olearacea var. capitata). J. Biochem. Technol., 4: 531-540.

Kuo, J-M., A. Hwang, D-B. Yeh, M-H. Pan, M-L. Tsai, and B. S. Pan (2006). Lipoxygenase from banana leaf: Purification and characterization of an enzyme that catalyzes linoleic acid oxygenation at the 9-position. J. Agric. Food Chem., 54: 3151-3156.

Labib, A. A. S. (1992). Chemical and technological studies on juices of some Egyptian fruits. Ph.D. Thesis, Faculty of Agriculture, Suez Canal University, Egypt.

Lokhandwala, A. and M. Bora (2014). Comparative analysis of Polyphenol Oxidase, Catalase and Lycopene production in Lycopersicon esculentum Mill. Inter. J. Current Microbiol. Applied Sci., 3: 969-983.

Lorenzi, V., J. Maury, J. Casanova and L. Berti (2006). Purification, product characterization and kinetic properties of lipoxygenase from olive fruit (Olea europaea L.). Plant Physiol. Biochem., 44: 450454.

MacDonald, L. and C. J. Schaschke (2000). Combined effect of high pressure, temperature and holding time on polyphenoloxidase and peroxidase activity in banana (Musa acuminata). J. Sci. Food Agric., 80: 719-724.

Martínez, G. A., P. M. Civello, A. R. Chaves and M. C. Añón (2001). Characterization of peroxidasemediated chlorophyll bleaching in strawberry fruit. Phytochem., 58: 379-387.

Matsui, K., K. Hijiya, Y. Tabuchi and T. Kajiwara (1999). Cucumber cotyledon lipoxygenase during postgerminative growth. Its expression and action on lipid bodies. Plant Physiol., 119: 1279-1287.

Mdluli, K. M. (2005). Partial purification and characterisation of polyphenol oxidase and 
peroxidase from marula fruit (Sclerocarya birrea subsp. Caffra). Food Chem., 92: 311-323.

Miller, A. R., T. J. Kelley and C. V. Mujer (1990). Anodic peroxidase isoenzymes and polyphenol oxidase activity from cucumber fruit: tissue and substrate specificity. Phytochem., 29: 705-709.

Nagle, N. E. and N. F. Haard (1975). Fractionation and characterization of peroxidase from ripe banana fruit. J. Food Sci., 40: 576-579.

Nelson, D. L. and M. M. Cox (2008). Lehninger Principles of Biochemistry. Macmillan, USA.

Ortega-García, F., S. Blanco, M. A. Peinado and J. Peragón (2008). Polyphenol oxidase and its relationship with oleuropein concentration in fruits and leaves of olive (Olea europaea) cv. 'Picual' trees during fruit ripening. Tree Physiol., 28: 45-54.

Quiroga, M., C. Guerrero, M. A. Botella, A. Barceló, I. Amaya, M. I. Medina, F. J. Alonso, S. M. de Forchetti, H. Tigier and V. Valpuesta (2000). A tomato peroxidase involved in the synthesis of lignin and suberin. Plant Physiol., 122: 11191128 .

Rayan, A. M. M. (2009). A study on thermostability of some quality-related fruit and vegetable enzymes. M.Sc. Thesis, Faculty of Agriculture, Suez Canal University, Egypt.

Regalado, C., B. E. García-Almendárez and M. A. Duarte-Vázquez (2004). Biotechnological applications of peroxidases. Phytochem. Reviews, 3: 243-256.

Robinson, S. P., B. R. Loveys and E. K. Chacko (1993). Polyphenol oxidase enzymes in the sap and skin of mango fruit. Australian J. Plant Physiol., 20: 99-107.

Saraiva, J. A., C. S. Nunes and M. A. Coimbra (2007). Purification and characterization of olive (Olea europaea L.) peroxidase: Evidence for the occurrence of a pectin binding peroxidase. Food Chem., 101: 1571-1579.

Sathya, M. (2014). Assaying the antioxidant activity of banana peel. American J. Biochem. Molecular Biol., 4: 122-129.

Sojo, M. M., E. Nunez-Delicado, F. García-Carmona and A. Sánchez-Ferrer (1998). Partial purification of a banana polyphenol oxidase using Triton X-114 and PEG 8000 for removal of polyphenols. J. Agric. Food Chem., 46: 49244930.

Son, S. M., K. D. Moon and C. Y. Lee (2001). Inhibitory effects of various antibrowning agents on apple slices. Food Chem., 73: 23-30.

Sugai, A. Y. and C. C. Tadini (2006). Thermal inactivation of mango (Mangifera indica $\mathrm{L}$. variety Palmer) puree peroxidase. VI International Symposium on Future of Food Engineering, Warsaw, Poland.

Suha, O. A., E. M. Babiker and E. E. Babiker (2013). Thermostability at different $\mathrm{pH}$ levels of peroxidase extracted from four vegetables. Inter. Food Res. J., 20: 715-719.

Terefe, N. S., R. Buckow and C. Versteeg (2014). Quality-related enzymes in fruit and vegetable products: effects of novel food processing technologies, part 1: high-pressure processing. Crit. Rev. Food Sci. Nutr., 54: 24-63.

Tipton, K. F. and H. B. F. Dixon (1983). Effect of pH on enzymes. In D. L. Purich (Editor). Contemporary Enzyme Kinetics and Mechanism. pp. 97-148. Academic Press, New York.

Tzika, E. D., T. G. Sotiroudis, V. Papadimitriou and A. Xenakis (2009). Partial purification and characterization of peroxidase from olives (Olea europaea cv. Koroneiki). Euro. Food Res. Technol., 228: 487-495.

Valero, E. and F. Garcia-Carmona (1992). Hysteresis and cooperative behavior of a latent plant polyphenoloxidase. Plant Physiol., 98: 774-776.

Valero, E. and F. Garcia-Carmona (1998). pHdependent effect of sodium chloride on latent grape polyphenol oxidase. J. Agric. Food Chem., 46: 2447-2451.

Whitaker, J. R. (1994). Principles of Enzymology for the Food Science. $2^{\text {nd }}$ Edition, New York, Marcel Deker.

Yadav, P., V. K. Singh, M. Yadav, S. K. Singh, S. Yadava and K. D. S. Yadav (2012). Purification and characterization of Mn-peroxidase from Musa paradisiaca (banana) stem juice. Indian J. Biochem. Biophysic, 49: 42-48.

Yang, C-P., S. Fujita, M. D. Ashrafuzzaman, N. Nakamura and N. Hayashi (2000). Purification and characterization of polyphenol oxidase from banana (Musa sapientum L.) pulp. J. Agric. Food Chem., 48: 2732-2735.

Yoruk, R. and M. R. Marshall (2003). Physicochemical properties and function of plant polyphenol oxidase: a review. J. Food Biochem., 27: 361422.

Zhow, H. and X. Feng (1991). Polyphenoloxidase from yali pear (Pyrus bretschneideri). J. Sci. Food Agric., 57: 307-313.

Zhu, Z., G. Wei, J. Li, Q. Qian and J. Yu (2004). Silicon alleviates salt stress and increases antioxidant enzymes activity in leaves of salt-stressed cucumber (Cucumis sativus L.). Plant Sci., 167: $527-533$ 


\section{الخصائص والنشاطات الأولية الكلية لثلاث إنزيمات مؤكسدة تم فصلها من بعض الفاكهة والخضر النامية في

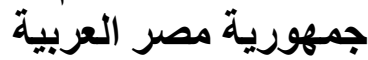

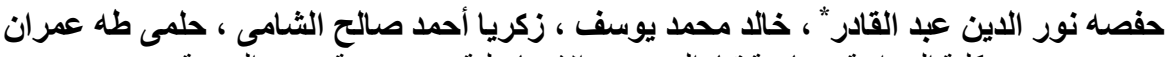

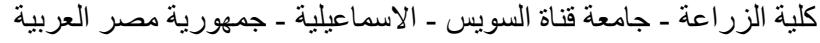

إن تو اجد بقايا نشاط الانزيمات الداخلية المرتبطة بجودة الخضر و الفاكهة سو اء في المنتجات الخام أو المصنعة قد يسبب فقد في الجودة

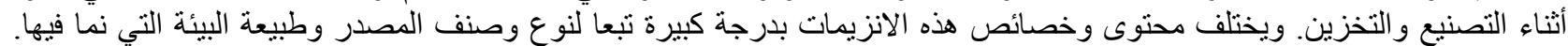

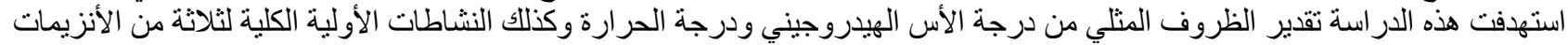

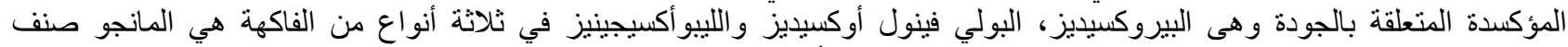

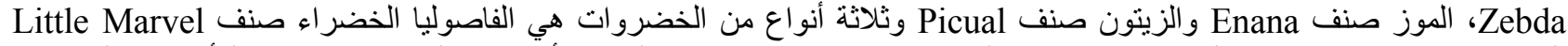

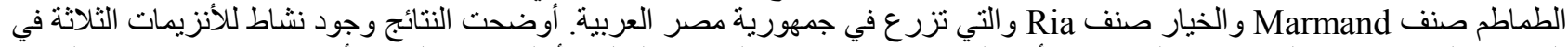

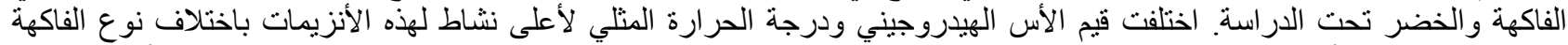



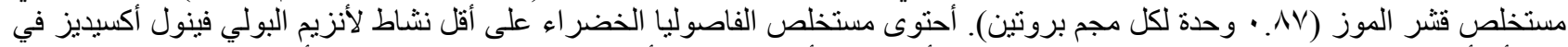

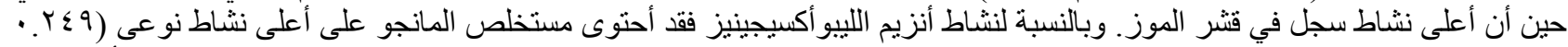

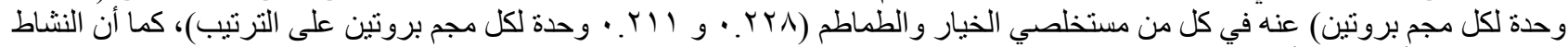

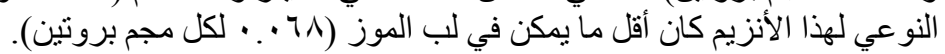

